\title{
Direitos fundamentais na tela da TV: uma análise do televisionamento de tribunais no Brasil
}

\author{
Fundamental rights on the TV screen: an analisys of courtroom television \\ broadcasting in Brazil
}

\author{
William Soares Pugliese* \\ Ricardo dos Reis Pereira*
}

\section{Resumo}

O artigo dialoga com o "argumento da lealdade constitucional", formulado em defesa do televisionamento de Tribunais Constitucionais. Para isso, o trabalho, inicialmente, faz uma breve contextualização da pesquisa nacional e internacional acerca do tema. Em seguida, apresenta de maneira objetiva os principais argumentos contrários e favoráveis a esse instrumento de transparência judicial, com especial ênfase no assim denominado "argumento da lealdade constitucional", que justifica o televisionamento sob a alegação de que a prática representa, ao mesmo tempo, um vetor de legitimação da jurisdição e um mecanismo para o acúmulo de "capital político" pela Corte, através da constante exposição das decisões majoritárias à população (o que cria um lastro que permite decidir casos contramajoritários futuros sem abalos institucionais). Ao final, o artigo demonstra que o "argumento da lealdade constitucional" deixou de considerar duas variáveis relevantes na sua formulação no contexto brasileiro: a seletividade da mídia na definição de quais julgamentos serão noticiados à sociedade, com uma tendência de maior reverberação de casos polêmicos (e contrajamoritários) e a possível corrosão da reserva de boa vontade da sociedade perante o STF, em razão do exercício da competência para julgamento penal de altas autoridades da República (prerrogativa de foro). Em conclusão, a presente crítica impõe uma reformulação do "argumento da lealdade constitucional" e os desvios apontados podem obstaculizar a adequada tutela jurisdicional dos direitos fundamentais no âmbito do Supremo Tribunal Federal.

Palavras-chave: Jurisdição constitucional. Televisionamento de tribunais. TV Justiça. Mídia.

\section{Abstract}

The paper offers a dialogue with the "constitutional loyalty argument", which was elaborated in defense of courtroom television broadcasting at Constitutional Courts. Initially, it presents a brief contextualization of both national and international research on the subject-matter. Then it introduces objectively the main arguments in favor and against this technic of judicial transparency, with a special attention to the so called "constitutional loyalty argument", which justifies courtroom television broadcasting under the allegation that it represents, at the same time, a legitimation of the constitutional adjudication and a way to accumulate "political capital" by the Court, through the constant public exposure of the majoritarian decisions to the population (which creates a ballast that allows the Court to decide countermajoritarian cases without any major institutional crisis). Finally, this paper demonstrates that the "constitutional loyalty argument" does not take into account two relevant variants in its formulation to the Brazilian context: the selectiveness of media outlets, which tend to overreverberate hot disputed cases (i.e. countermajoriarian cases) and the possible corrosion of the population's reserve of good will towards the Court due to its criminal trial cases against important political authorities. In conclusion, it will be stated that this critique demands a reformulation of the "constitutional loyalty argument" and that the adjudication of fundamental rights can be harmed at the Brazilian Supreme Court because of these deviations.

Keywords: Constitutional adjudication. Television courtroom broadcasting. TV Justiça. Media.

Doutor e Mestre em Direito pelo Programa de Pós-Graduação da Faculdade de Direito da Universidade Federal do Paraná. Professor do Programa de Pós-Graduação em Direito da UniBrasil, em Curitiba/PR. Curitiba - PR- Brasil. E-mail: wpugliese@gmail.com.

Mestrando em Direitos Fundamentais e Democracia no Programa de Pós-Graduação em Direito do Centro Universitário Autônomo do Brasil UniBrasil, em Curitiba/PR. Bolsista PROSUP/CAPES. Curitiba - PR- Brasil. E-mail: ricardo@rrp.adv.br. 


\section{Introdução}

O presente artigo propõe um diálogo com o "argumento da lealdade constitucional", que foi desenvolvido por Felipe de Melo Fonte (2016) em defesa das práticas de televisionamento de Cortes Constitucionais em seu livro "Jurisdição Constitucional e Participação Popular: o Supremo Tribunal Federal na era da TV Justiça".

O texto, inicialmente, faz uma contextualização da pesquisa nacional e internacional acerca do tema, no item 2, demonstrando que o assunto foi sempre muito candente na academia norte-americana ("television courtroom broadcasting"), sendo investigado sob as mais variadas abordagens metodológicas, mas que, no Brasil, a questão só veio a receber maior atenção dos pesquisadores a partir de 2002, quando da criação da TV Justiça no âmbito do Supremo Tribunal Federal.

No item 3, trazem-se, para a colação preliminar do leitor, os principais argumentos doutrinários favoráveis e contrários ao televisionamento de tribunais, os quais geralmente se relacionam, respectivamente, às ideias de controle democrático do Poder Judiciário ou da discrição da atividade judicial. Ainda no item 3 , apresenta-se objetivamente o "argumento da lealdade constitucional", através do qual Felipe de Melo Fonte sustenta que o televisionamento de Tribunais Constitucionais é uma prática recomendável porque: $i$ ) oferece às Cortes um importante instrumento de legitimação da sua própria jurisdição (através dos mecanismos descritos pela teoria do viés da positividade) e ii) cria uma "reserva de boa vontade" da sociedade em favor dos Tribunais, por meio da constante exposição televisiva das suas decisões que, via de regra, são "majoritárias", no sentido de que julgam de acordo com a maioria da opinião pública.

Na sequência, demonstra-se que, para Felipe de Melo Fonte, essa "reserva de boa vontade" se transforma em uma espécie de capital político que permite à Corte tomar decisões impopulares (contramajoritárias) no futuro, motivo pelo qual o autor sustenta que o televisionamento reforça a independência do Tribunal Constitucional e, muito especialmente, colabora para a adequada tutela dos direitos fundamentais (que, muitas vezes, exige a tomada de decisões marcadamente contramajoritárias).

No item 4 é elaborada a tese central do artigo, segundo a qual o "argumento da lealdade constitucional", tal como formulado, é inadequado e inaplicável à realidade brasileira, porque ignora duas variáveis fáticas decisivas para o correto funcionamento desse sistema de formação da "reserva de boa vontade" em favor do Supremo Tribunal Federal.

Com base em argumentação lógico-dedutiva, sustenta-se que o televisionamento do STF não leva à formação da reserva de boa vontade, porque a maioria da população ainda acessa o noticiário judiciário através dos canais regulares da televisão, e não através da TV Justiça. Assim, ao invés de serem expostos a um maior número de decisões majoritárias da Corte (através da programação da TV Justiça), os cidadãos acabam sendo expostos muito mais às decisões contramajoritárias, pois as companhias de comunicação fazem escolhas editoriais para valorizar comercialmente o seu produto - a notícia -e, por isso, publicam mais decisões "polêmicas", criando uma espécie de filtro na comunicação do STF com o cidadão brasileiro.

De igual maneira, o argumento se mostra incompatível com a realidade jurídica brasileira, porque o STF não exerce apenas as atribuições de um Tribunal Constitucional, mas também a extravagante competência de julgar criminalmente as altas autoridades da República (prerrogativa de foro). Assim, também a percepção popular acerca da atuação da Corte nesses julgamentos teria que ser levada em consideração na teorização de um tal sistema de formação da reserva de boa vontade.

Em conclusão, afirma-se que esses desvios têm a capacidade de desequilibrar, ou mesmo impossibilitar, o correto funcionamento da teoria de Felipe Melo Fonte. Afinal, se o televisionamento do STF não ajuda na formação da reserva de boa vontade na sociedade, então, certamente, não pode ser defendido sob a alegação de que reforça a independência judicial da Corte, nem tampouco de que cria um "escudo" institucional que colaboraria para a tutela adequada dos direitos fundamentais. 


\section{0 debate acadêmico sobre o televisionamento de tribunais nos Estados Unidos da América e no Brasil}

A publicidade do Poder Judiciário, ou, mais especificamente, o televisionamento de tribunais, é um tema célebre entre os pesquisadores do Direito nos Estados Unidos da América, onde há densa produção acadêmica praticamente desde o advento da televisão ao vivo (YESAWICH JR., 1952). Em regra, os estudiosos tentam responder a pergunta: o televisionamento das sessões de julgamentos influencia os atores processuais de alguma maneira?

As hipóteses fundamentais, sobre as quais todos os demais problemas parecem se desenvolver, são estas: i) o televisionamento não influencia os participantes do processo (as pessoas conseguem abstrair o fato de estarem sendo filmadas), sendo indiferente para a jurisdição; ii) o televisionamento influencia positivamente os participantes (as pessoas agem de maneira mais responsável ao saberem que estão sendo filmadas), colaborando para uma melhor jurisdição, ou iii) o televisionamento influencia negativamente os atores processuais (as pessoas ficam nervosas e agem erraticamente, por exemplo), prejudicando a jurisdição. ${ }^{1}$

Cada uma dessas hipóteses traz profundas implicações sobre as práticas de televisionamento de Tribunais. Afinal, por exemplo, se uma testemunha age diferentemente diante de câmeras de TV, então haveria um grave problema na produção da prova. $\mathrm{E}$, de maneira muito especial, se o televisionamento influencia o processo decisório do juiz ou dos jurados, então haveria um grave problema para a própria jurisdição, afinal a sentença estaria fraudada por fatores externos.

Nesse sentido, a academia norte-americana realizou diversas abordagens metodológicas para tentar responder esses intrincados questionamentos, através de pesquisas empíricas e experimentos comportamentais (FONTE, 2016, p. 77), atingindo um notável avanço na pesquisa, contudo, sem atingir um consenso.

Ainda hoje o debate continua aberto nos Estados Unidos e a maior prova disso é que a Suprema Corte ainda mantém sua centenária tradição de realizar as sessões de julgamentos a portas fechadas, sem qualquer transmissão ao público externo, ${ }^{2}$ em que pesem diversas manifestações do Congresso americano em sentido oposto, ${ }^{3}$ em nome de maior publicidade e controle democrático.

No Brasil, o assunto nunca havia chamado atenção da comunidade acadêmica, só entrando no radar dos pesquisadores a partir da criação da TV Justiça, ${ }^{4}$ através da Lei Federal n. 10.461, de 17 de maio de 2002, quando as sessões de julgamento do Supremo Tribunal Federal passaram a ser transmitidas pela televisão, rádio e internet, ao vivo e sem edições. A partir de então, nossa doutrina repisou alguns passos já dados pela pesquisa norte-americana e também promoveu desenvolvimentos e adaptações necessárias à singular realidade brasileira. ${ }^{5}$

O interesse pelo tema só fez crescer. A cada ano são publicadas novas pesquisas sobre a TV Justiça nas universidades (HARTMANN et al., 2017; BORGES; ROMANELLI, 2016; SILVA, 2013) e, mesmo fora delas, o problema atingiu uma relevância notável. Personalidades da política e do Direito parecem ter sempre

Haveria uma quarta hipótese, segundo a qual é impossível conhecer objetivamente os efeitos que o televisionamento tem sobre os atores processuais. Mas trata-se, na verdade, do reconhecimento de uma barreira epistemológica, e não propriamente de uma hipótese de resolução do problema proposto.

2 O regulamento interno da Corte Suprema dos EUA é expresso neste sentido: "Recording or broadcasting of the announcement in any manner is prohibited (ESTADOS UNIDOS DAAMÉRICA. Supreme Court, 2017)

3 Vide Resolução n. 339 do Senado dos EUA, subscrita por dez congressistas em 2010: "Resolution [...] to express the sense of the Senate in support of permitting the televising of Supreme Court proceedings (ESTADOS UNIDOS DAAMÉRICA. U.S. Congress, 2010)

4 O fato demonstra a prematuridade da criação da TV Justiça, que não foi precedida de nenhum estudo de impactos (em que pese a vasta doutrina de direito comparado), sendo fruto do empenho pessoal do ministro Marco Aurélio, conforme opinião de seus próprios colegas: "A ausência de negociação parece ter gerado desconforto entre os ministros do Supremo, uma vez que todos os que fazem referência ao processo de criação da TV Justiça destacam ter sido obra exclusiva do ministro Marco Aurélio" (SANTOS, 2017, p. 228).

5 A principal diferença entre o debate acadêmico no Brasil e nos Estados Unidos é que, por aqui, se pensa quase que exclusivamente no televisionamento do Tribunal Constitucional (STF), enquanto que, nos Estados Unidos, há vasta produção acadêmica sobre o televisionamento de tribunais inferiores, sobretudo em matéria criminal (efeito das câmeras sobre testemunhas e jurados, principalmente). 
alguma coisa a opinar ${ }^{6}$ sobre o assunto da exposição midiática do Supremo Tribunal Federal, havendo até projetos de lei que pretenderam acabar com as transmissões ao vivo. ${ }^{7}$

Por aqui também não se atingiu um consenso, portanto. Continua-se tentando compreender que efeitos o televisionamento das sessões de julgamento do STF produz sobre a jurisdição constitucional (se é que produz algum efeito). E dentre vários questionamentos relevantes, um nos parece particularmente problemático e fascinante, porque relacionado ao cerne do constitucionalismo: o televisionamento do STF faz com que os juízes constitucionais sejam pressionados a julgar em favor da opinião pública majoritária (populismo judicial ${ }^{8}$ ), em indevido constrangimento da tutela adequada (MARINONI, 2018) dos direitos fundamentais (que muitas vezes exige decisões judiciais contrárias à maioria da opinião pública)?

A ideia parece intuitiva: os juízes constitucionais, homens e mulheres de carne e osso, certamente devem ser suscetíveis a algum tipo de influência da opinião pública, muito especialmente em um momento em que o Supremo Tribunal Federal ocupa um lugar de destaque central no desenho político-institucional do Estado Constitucional brasileiro (VIEIRA, 2008). Os juízes constitucionais sabem que seus votos serão estampados à exaustão nos jornais no dia seguinte e suas falas transmitidas nos canais de televisão justamente nos excertos em que sejam mais polêmicos, sendo verossímil imaginar que essa consciência exerça alguma influência sobre seus comportamentos.

Esse questionamento - entre muitos outros - foi abordado com grande competência na obra intitulada Jurisdição Constitucional e Participação Popular - O Supremo Tribunal Federal na era da TV Justiça, de Felipe de Melo Fonte (2016). Sob a orientação do professor e ministro do STF, Luís Roberto Barroso, o autor apresenta a tese de seu doutoramento que resgata o estado da arte da discussão para, em seguida, argumentar que a TV Justiça não constrange a tutela de direitos fundamentais.

Para tanto, o autor antes revisita a pesquisa norte-americana acerca do tema (FONTE, 2016, p. 77), analisa as experiências concretas de televisionamento judicial (FONTE, 2016, p. 41), apresenta os impactos qualitativos e quantitativos da TV Justiça sobre a atividade do STF (em pesquisa empírica de notável relevância (FONTE, 2016, p.119)), rebate um a um os argumentos contrários ao televisionamento de tribunais, e, ao final, faz uma exposição apologética ao televisionamento de cortes constitucionais (FONTE, 2016, p. 177), sustentando que a conjunção da teoria do viés da positividade (GIBSON; CALDEIRA, 2009) ao conceito de "capital institucional" (RIBEIRO, 2015) comprova que a prática reforça a independência do Tribunal, criando melhores condições para o julgamento de casos contramajoritários.

Em que pese o brilhantismo da obra e originalidade da contribuição, o presente trabalho pretende demonstrar que o pensamento de Felipe Melo Fonte deixou de considerar variáveis fáticas importantes para a aplicação dessa teoria, especialmente no Brasil: a seletividade da mídia na difusão dos julgamentos e os efeitos da competência para julgamento penal de altas autoridades políticas (prerrogativa de foro) para a imagem institucional do STF. A contribuição que se oferece, portanto, estaria a exigir uma releitura da teoria nesse aspecto.

\section{Os argumentos contrários e favoráveis ao televisionamento de cortes constitucionais e o "argumento da lealdade constitucional"}

Fazendo uma contextualização da pesquisa acadêmica sobre o assunto e trazendo à colação do leitor, virtualmente, todas as descobertas relevantes já produzidas pela doutrina, Felipe de Melo Fonte

\footnotetext{
Um exemplo de destaque é a manifestação do ex-presidente Fernando Henrique Cardoso, que afirmou textualmente ter dúvidas acerca da conveniência da TV Justiça e insinuou que só não a extinguiria, se pudesse, porque poderia ser interpretado como anti-democrático (e não porque a TV Justiça merecesse continuar existindo (CARVALHO, 2010).

Projeto de Lei n. ${ }^{\circ} 7.004 / 2013$, do Deputado Federal Vicente Cândido (PT-SP).

8 Comentando um "bate-boca" entre os ministros Gilmar Mendes e Joaquim Barbosa, em 2009, Virgílio Afonso da Silva e Conrado Hübner Mendes (2009) alertavam, à época, sobre o risco do "populismo judicial" causado pelo televisionamento, valendo-se do pretexto de uma suposta transparência: "Saber se a discussão entre os ministros Gilmar Mendes e Joaquim Barbosa fere a imagem do tribunal não é tão relevante quanto o sintoma que esse episódio pode representar: alguns ministros começam a aproveitar o 'momentum' televisivo para dirigir-se exclusivamente ao público externo, em vez de interagir entre si, no melhor espírito de uma deliberação colegiada. Tornam-se celebridades, o que é perigoso. Talvez estejam produzindo, a título de uma sedutora transparência de superfície, um indesejável populismo judicial. O tribunal vende uma e entrega o outro. E não percebemos" (SILVA; MENDES, 2009).
} 
organiza as ideias do texto através de uma compilação dos principais argumentos favoráveis e contrários ao televisionamento de tribunais (FONTE, 2016, p. 13).

Importa-nos expor esses argumentos contrários, ainda que superficialmente. Contra o televisionamento de tribunais em geral (não apenas de cortes constitucionais), citam-se três argumentos fundamentais: i) os efeitos desconhecidos da prática (FONTE, 2016, p. 28); ii) a possível transformação da justiça em entretenimento (FONTE, 2016, p. 31) e iii) a proteção da intimidade e privacidade das partes (FONTE, 2016, p. 33).

Em relação aos "efeitos desconhecidos", o autor explica que os defensores dessa posição afirmam que, como a ciência ainda não foi capaz de oferecer uma resposta conclusiva sobre como os atores processuais são influenciados pelas câmeras de TV (se é que o são de alguma maneira), seria imprudente estabelecer o televisionamento dos tribunais antes de um conhecimento mais aprofundado sobre o assunto. ${ }^{9}$

Quanto à possível transformação da justiça em entretenimento, pode-se resumir a ideia no famoso termo "espetacularização do Judiciário", que transmite o sentimento de que a exposição indiscriminada das Cortes ao público em geral pode levar à banalização da atividade judiciária perante os cidadãos, que passam a perder o respeito pela autoridade da jurisdição. ${ }^{10}$

Por fim, o argumento de proteção da intimidade das partes parece autoevidente: o televisionamento dos Tribunais violaria o direito das partes de serem resguardadas de qualquer devassa pública. Essa visão, que parece ter singular alcance nos processos de natureza criminal ou de direito de família, também é um dos argumentos comumente opostos às pretensões de televisionamento de tribunais.

Propondo-se a superar esses argumentos contrários ao televisionamento de tribunais, o autor formula também a lista dos seus argumentos (FONTE, 2016, p. 177), segundo os quais o televisionamento de tribunais constitucionais seria uma política recomendável. São eles: i) "o argumento de lealdade constitucional": a exposição pública da atividade dos tribunais teria o condão de aumentar a adesão pública à ordem constitucional vigente (FONTE, 2016, p. 177); ii) "o argumento da pluralidade hermenêutica": a adesão popular à interpretação constitucional teria o potencial de aumentar o "estoque de ideias" e servir como "norte interpretativo" (FONTE, 2016, p. 207); iii) "o argumento dos espaços cívicos": em uma sociedade de baixa participação política, a abertura da corte ao público poderia proporcionar a criação de novos espaços cívicos (FONTE, 2016, p. 233) e, finalmente, iv) "o argumento da pedagogia democrática": a difusão do discurso das cortes constitucionais tem um valor importante na consolidação dos valores democráticos em uma sociedade (FONTE, 2016, p. 257).

Todos os argumentos solidamente construídos são tratados, merecendo atenção detida em todos os seus aspectos e complexidades. Todavia, o presente artigo se debruçará especificamente sobre o chamado "argumento da lealdade constitucional", pois se acredita que o autor tenha deixado de observar variáveis relevantes para o correto funcionamento da teoria, especialmente se o argumento for pensado no contexto brasileiro.

O referido argumento parte da conjunção de dois conceitos distintos: a ideia de "símbolos de legitimação" (FONTE, 2016, p. 191), oriundos da teoria norte-americana do "viés da positividade" (theory of positivity bias) de James L. Gibson e Gregory Caldeira (2009, p. 728), e o conceito de "capital institucional” (FONTE, 2016, p. 196) desenvolvido por Pedro José de Almeida Ribeiro (2015, p. 311). Ao fim de seus esforços, Felipe de Melo Fonte dirá que o televisionamento não apenas estimula a legitimação da jurisdição constitucional, como ainda lhe fornece uma espécie de antídoto contra o eventual constrangimento majoritário que poderia advir da exposição dos juízes à população.

9 Esse argumento parece especialmente relevante no contexto brasileiro, em que a criação da TV Justiça não foi precedida de nenhum debate acadêmico.

10 Em clássica passagem de seu livro-reportagem sobre o julgamento de Adolf Eichmann em Jerusalém, também citada por Felipe de Melo Fonte, Hannah Arendt (1999, p. 16) tocava com profunda sensibilidade no tema da espetacularização do Judiciário, afirmando que a "[...] justiça não admite coisas desse tipo, ela exige isolamento, admite mais tristeza do que raiva, e pede a mais cautelosa abstinência diante de todos os prazeres de estar sob a luz dos refletores". 
Valendo-se das doutrinas de Konrad Hesse ("vontade de constituição") e Pablo Lucas Verdú ("sentimento constitucional"), o autor inicia sua análise a partir do consenso da teoria constitucional de que "uma ordem constitucional que pretenda ser duradoura depende da aquiescência pública" (FONTE, 2016, p. 177). Segundo recorda, a jurisdição constitucional exige sempre algum grau de legitimidade perante o povo:

\begin{abstract}
A concordância com as decisões individuais da Corte não se confunde com o apoio difuso à própria existência dela e da justiça constitucional. De todo modo, parece certo que a interpretação da Constituição precisa refletir, em alguma medida, a vontade do povo. [...] É certo que o significado da Constituição, tal como construído pela Corte, não deve e não pode ser objeto de total aquiescência popular, durante todo o tempo, exigência que transformaria tanto a jurisdição constitucional quanto o constitucionalismo em práticas inúteis e irrealizáveis. Todavia, ela deve, no mínimo, considerar as visões públicas sobre o que requer a justiça constitucional. Se os juízes constitucionais acreditam que o público está equivocado, eles devem considerá-lo e dizê-lo de modo explícito, preferencialmente em linguagem acessível à sociedade (FONTE, 2016, p. 186).
\end{abstract}

Isto se dá porque os tribunais, exercendo um poder que é jurídico, mas também político, precisam se justificar permanentemente perante a sociedade, de modo a cultivarem uma legitimidade que ofereça razões racionais aceitáveis para que sua autoridade siga sendo respeitada. Enquanto os poderes majoritários Executivo e Legislativo - o fazem através do voto regular, o Poder Judiciário precisaria fazê-lo através da exposição ao público em geral de suas interpretações constitucionais que, "em alguma medida", deverão refletir a vontade do povo.

Essa constatação é tão antiga quanto o constitucionalismo e está perfeitamente formulada já no Federalista $n .{ }^{\circ} 78$, quando Madison e Hamilton lembravam que o Poder Judiciário não tinha a "espada" do Executivo e nem a "bolsa" do Legislativo, devendo valer-se de persuasão racional para fazer-se aceito enquanto poder (FONTE, 2016, p. 187).

A questão, para Felipe Melo Fonte, é partir desse consenso para uma questão bem mais problemática: como promover essa constante legitimação na prática? Será que o televisionamento dos Tribunais Constitucionais contribuiria nesse sentido?

Para responder afirmativamente ao questionamento, o autor aportará à sua pesquisa a mencionada teoria do viés da positividade (theory of positivity bias) de James L. Gibson e Gregory Caldeira, para quem "qualquer coisa que faça as pessoas prestarem atenção às cortes - inclusive controvérsias - acaba reforçando sua legitimidade institucional por meio da exposição dos símbolos de legitimação associados ao direito e aos tribunais" (GIBSON; CALDEIRA, 2009, p. 125).

Embora Gibson e Caldeira estivessem originariamente mais interessados nos impactos que o processo de escolha de juízes para a Suprema Corte dos EUA tem perante a sociedade americana (FONTE, 2016, p. 190-191), suas hipóteses são aplicáveis ao recorte de pesquisa proposto por Felipe de Melo Fonte, como se verá.

É que a teoria da positividade afirma que quando os cidadãos são expostos aos chamados "símbolos de legitimação" dos Tribunais, como o "uso de togas, colares, palavras de ordem" (FONTE, 2016, p. 191), os valores tradicionalmente ligados a essas instituições - imparcialidade, justiça, racionalidade - são reafirmados na psique do espectador, colaborando para sua legitimação. Trata-se de uma teoria semiótica, portanto, em que símbolos comunicam informações.

A ideia é interessante e merece uma reflexão mais detida: não é difícil pensar que o televisionamento dos juízes do STF no momento em que decidem os casos em suas togas pretas, sob o brasão da República, declarando em tom grave o teor de suas sentenças proferidas no solene jargão jurídico (muitas vezes intangível à população), poderia imprimir no inconsciente do cidadão comum, em um nível psicológico muito fundamental, a ideia de autoridade do Poder Judiciário, que ficaria assimilada por todos como sendo algo dado e virtualmente inquestionável. O televisionamento do STF trabalharia em favor de sua legitimação enquanto órgão jurídico-político, por assim dizer.

Só que Felipe de Melo Fonte percebe que essa interessante construção não resolve o problema do julgamento dos casos contramajoritários. Afinal, ainda que o televisionamento promova a legitimação do 
STF, através da constante apresentação de seus "símbolos de legitimação" à população, nada impedirá que seus juízes ainda continuem constrangidos a seguirem posições majoritárias, sobretudo porque expostos aos holofotes da TV Justiça e, portanto, sob o severo crivo da opinião pública.

Para superar definitivamente a questão e arrematar sua argumentação, Felipe Melo Fonte (2016, p.193) agrega à teoria do viés da positividade o conceito de "capital institucional" para dizer que o "suporte difuso", ${ }^{11}$ alimentado no curso de longos períodos de decisões majoritárias, fornece suficiente lastro institucional ao Tribunal Constitucional no momento de decidir questões contramajoritárias, nas quais sempre haverá forte resistência popular.

Assim sendo, considerando que desde há muito Robert Dahl (1957) mostrou que as Cortes Constitucionais, na maioria das vezes, tomam decisões majoritárias, que seguem a opinião pública (FONTE, 2016, p. 195), esses julgamentos, quando televisionados, fornecem um estímulo para a formação do que David Easton (1968) chamou de "reserva de boa vontade" ("reserve of good will") junto à população, que vai entendendo que o sistema tem uma racionalidade aceitável e merece ser respeitado por todos. O Tribunal Constitucional vai, pouco a pouco, amealhando um capital institucional, para "gastá-lo" quando for necessário decidir contramajoritariamente. Afirma Felipe de Melo Fonte (2016, p. 195-196):

É por este motivo que as cortes constitucionais normalmente apoiam as decisões majoritárias, conforme primeiramente apontado por Robert Dahl, e discutido mais recentemente por Corina Barret Lain, Robert Pildes e Thamy Progrebinschi, esta última no Brasil. Os tribunais constitucionais placitam políticas majoritárias e decidem em conformidade com a opinião popular na maior parte do tempo, de modo a acumular capital para que possam decidir contra as maiorias sem causar rupturas sistêmicas.

Assim é que o autor conclui dizendo que, tendo legitimado sua própria jurisdição através do televisionamento (segundo a teoria do viés da positividade) e tendo adquirido mais e mais capital institucional nas seguidas decisões majoritárias também televisionadas (apoio difuso), o Tribunal Constitucional televisionado terá mais força institucional para tomar decisões contramajoritárias do que tribunais não televisionados (afinal, esses não terão sido legitimados pela exposição de seus símbolos, tampouco terão recebido a "reserva de boa" vontade nos julgamentos majoritários). Nas palavras do autor:

Mas o ponto central que se quer chamar atenção aqui é a combinação entre a ideia de capital institucional e a positivity theory, que permite formular um argumento claro contra a associação entre publicidade e perda do respeito pelas instituições judiciais ou enfraquecimento da sua função contramajoritária. Como visto acima, ao ampliar o conhecimento sobre a jurisdição constitucional, o televisionamento tende a maximizar a percepção geral de legitimidade que ela ostenta. Traduzindo para o discurso de Easton, o que se tem é simples e puro aumento da "reserva de boa vontade" em favor da corte constitucional. [...] Em resumo: uma corte constitucional televisionada tem maior poderio para produzir decisões contramajoritárias do que cortes efetivamente insuladas das maiorias tradicionais (FONTE, 2016, p. 196).

Embora muito bem apresentado, o argumento parece ignorar algumas variáveis fundamentais para a sua correta formulação, especialmente quando considerado o contexto brasileiro. É o que se passa a expor no item seguinte.

\section{Crítica ao "argumento de lealdade constitucional": a seletividade da mídia como desvio não considerado no mecanismo de aquisição de capital institucional e os efeitos do exercício da competência da "prerrogativa de foro" para a imagem do STF}

A teoria de Felipe Melo Fonte parece funcionar perfeitamente quando imaginamos que a população brasileira assiste à TV Justiça de forma equânime, acompanhando igualmente os julgamentos do STF,

\footnotetext{
11 Por "suporte difuso" entenda-se um apoio mais qualificado à atuação da Corte Constitucional, em que os cidadãos identificam, nos julgamentos do Tribunal, ainda que contrários aos seus interesses pessoais diretos, o exercício de uma jurisdição que traz benefícios ao sistema político em longo prazo, merecendo a autoridade que possui. É mais qualificado, portanto, que o "suporte específico", que as pessoas oferecem ao Tribunal Constitucional quando esse julga favoravelmente as causas de seu próprio interesse (por exemplo, quando a comunidade negra apoia a declaração de constitucionalidade da política de cotas raciais (FONTE, 2016)).
} 
majoritários e contramajoritários, em todas as matérias. Nesse cenário ideal, de fato, a teoria da positividade e os conceitos de capital institucional e apoio difuso parecem levar a uma inexorável conclusão de que o televisionamento colabora não apenas para a legitimação da jurisdição, mas ainda fornece lastro institucional para decisão de casos contramajoritários.

O problema que a construção teórica parece ignorar é que, no mundo real dos fatos, não são todos os julgamentos do STF que chegam indistintamente às televisões dos cidadãos, com igual exposição. Ao contrário, os julgamentos majoritários, que forjariam o apoio difuso e o capital institucional da Corte, não parecem ter a mesma reverberação midiática dos casos contramajoritários, que são, por definição, mais polêmicos.

Para explicar o raciocínio, em primeiro lugar, é importante recordar que os julgamentos do STF são apresentados à população através do filtro da mídia tradicional, por meio da transmissão de excertos dos votos dentro da pauta dos jornais ou telejornais. ${ }^{12}$ É muito difícil acreditar que uma parcela significativa do povo (significativa para a formação da opinião pública) assista ao conteúdo judicial diretamente na TV Justiça, acompanhando as longas horas, às vezes dias, de votação ao vivo e sem edição.

Ademais, deve-se ter em mente que, em razão de um apelo comercial - os canais de TV disputam um consumidor -, os telejornais precisam valorizar suas notícias, e certamente o fazem, num primeiro momento, escolhendo o que é notícia e o que não é, o que entra na pauta e o que não entra. Aí reside o poder que comumente se atribui ao jornalismo: "[...] notícia é todo o fato relevante que desperte interesse público, ensinam os manuais de jornalismo. Fora dos manuais, notícia, na verdade, é tudo que os jornalistas escolhem oferecer ao público" (NOBLAT, 2008, p. 31).

E mais, após essa escolha, os editores dos telejornais certamente ainda podem fazer uma polemização das notícias que entraram na pauta, dando ênfase aos excertos das decisões judiciais que tenham mais "apelo" popular, isto é, priorizando o teor das decisões que seja excêntrico, menos usual, de modo justamente a atrair mais atenção do telespectador.

E a própria definição do que venha a ser o não usual, o excêntrico, o espetacular em matéria de decisões judiciárias que parece ser, em grande parte, coincidente com o conceito de decisão contramajoritária. Ora, polêmica é a decisão contramajoritária que desafia o senso comum; a decisão majoritária é apenas usual e previsível. Assim, poderia se argumentar a existência de uma tendência a incluirem nas pautas dos telejornais mais decisões contramajoritárias do que majoritárias, pois aquelas chamariam mais atenção do público espectador.

Desse modo, os julgamentos majoritários que encampam aos valores percebidos como corretos pela maioria da população (e que levariam ao acúmulo de apoio difuso e capital institucional) não terão recebido igual atenção da mídia e, por consequência, não terão chegado ao conhecimento da massa popular - ao menos não com a mesma intensidade e destaque jornalístico dos julgamentos contramajoritários.

Por essa razão é que se afirma que, confirmada essa tendência, haverá um importante desvio no mecanismo de construção do capital institucional e, portanto, um desequilíbrio no funcionamento da teoria proposta por Felipe de Melo Fonte (nesse argumento específico, é claro).

Ora, se o televisionamento do Tribunal Constitucional não funciona corretamente para construir o apoio difuso que leva à capitalização institucional, então o argumento de lealdade não se sustenta em um ponto absolutamente central: na formação do "escudo" institucional que protege a Corte para a tomada de decisões contramajoritárias (i.e. na tutela de direitos fundamentais, muito especialmente).

Não se ignora que, para responder adequadamente todas essas provocações, haveria que se fazer pesquisa empírica que verificasse, quantitativamente e qualitativamente, a cobertura que a mídia oferece às decisões do STF, relacionando cada uma delas à opinião pública sobre o seu respectivo tema (para classificá-las como majoritárias e contramajoritárias, no sentido aqui utilizado). Não tendo tal estudo sido

12 A presença do STF no noticiário da mídia tradicional foi objeto de importante pesquisa empírica, realizada por Joaquim Falcão e Fabiana Luci de Oliveira (2013). 
ainda realizado, ${ }^{13}$ o presente artigo pretende apenas expor uma variável que, acredita-se, deveria ter sido considerada quando da formulação do argumento da lealdade, por Felipe Melo Fonte.

Em caráter meramente ilustrativo e sem nenhuma pretensão de "provar" a tese deste trabalho, trazse à colação do leitor o estudo organizado por Fabiana Luci de Oliveira intitulado "Decisões do Supremo Tribunal Federal" (2011), realizado pela FGV-Rio, no qual 1.200 pessoas foram entrevistadas e responderam sobre quais notícias judiciárias tinham lhe chamado mais atenção, logo em seguida relacionando esses resultados à opinião de cada entrevistado sobre o acerto ou erro da decisão do STF.

Os resultados sugerem que as pessoas tendem a extrair do noticiário judicial aqueles casos mais polêmicos, tendo pouco conhecimento acerca de casos menos polêmicos. Isto poderia sinalizar a tendência que se sustenta aqui, de que a mídia tem uma predileção, de natureza comercial (ou possivelmente de natureza ideológica, a depender do tema da decisão), pela reverberação de notícias mais apelativas, que causem maior impacto nos cidadãos.

Nessa pesquisa específica, os três fatos judiciários que mais atraíram a atenção da população foram os seguintes julgamentos do STF: o "reconhecimento da união homoafetiva", o "caso Cesare Battisti" e a liberação da "Marcha da Maconha". Sugerindo (não provando) o que se afirma dedutivamente aqui (o recorte da pesquisa é estrito demais para afirmar uma tendência objetiva), dois desses julgamentos foram contramajoritários, no sentido do termo aqui empregado, pois $66 \%$ das pessoas discordaram da decisão do STF quanto à concessão de liberdade a Cesare Battisti e 51\% discordaram da decisão de autorizar a "Marcha da Maconha". No julgamento da União Estável de casais homossexuais, 44\% dos entrevistados discordaram da decisão do STF. ${ }^{14}$

Com a pesquisa acima mencionada, sabidamente um recorte metodológico muito restrito - inadequado para sustentar a tese do presente trabalho -, há uma mera ilustração do fenômeno aqui teorizado: as decisões mais polêmicas chegam mais ao conhecimento das pessoas através da mídia tradicional, exatamente porque contramajoritárias. Esse fato, que pode ser confirmado futuramente através de pesquisas empíricas mais abrangentes, certamente colocaria em xeque o correto funcionamento da teoria proposta por Felipe de Melo Fonte, ao menos no que diz respeito ao argumento da lealdade constitucional e a (suposta) capacidade de o televisionamento criar condições mais favoráveis ao julgamento de casos contramajoritários, aí especialmente incluídos os casos que tratam de direito fundamentais.

Isto porque, relembre-se, Felipe de Melo Fonte baseia toda a sua argumentação na ideia de que a constante exposição televisiva das decisões majoritárias do STF cria uma "reserva de boa vontade" nos cidadãos, que se transforma no "capital político" que permitirá a tomada de decisões impopulares no futuro, sem maiores traumas. Entretanto, se a mídia tradicional desvirtua esse sistema ao noticiar mais decisões contramajoritárias do que majoritárias, então, aparentemente, poder-se-ia sugerir um estímulo à formação de algo como uma "reserva de má vontade", isto é, os cidadãos estariam constantemente expostos a decisões que não encampam seus interesses e opiniões, o que certamente trabalharia contra a construção de uma imagem pública favorável à Corte. ${ }^{15}$

Por fim, há outro desvio que se poderia argumentar na aplicação dessa teoria à realidade brasileira: por aqui, o Supremo Tribunal Federal não é exposto pela televisão apenas na qualidade de Corte Constitucional

13 Desconhece-se a existência de estudos empíricos que tenham cruzado dados sobre a exposição midiática das decisões proferidas pelo STF com estudos sobre opinião pública a respeito dos temas decididos (para confirmar se há uma maior publicação de casos contramajoritários). Todavia há pesquisas que indicam claramente a existência de um desvio decorrente da "seletividade da mídia" na reverberação das decisões do Tribunal. Por exemplo, já se identificou uma (super)exposição de temas que não povoaram tanto a pauta da Corte, bem como a construção pelo jornal Folha de São Paulo de uma imagem eminentemente política do STF (OLIVEIRA, 2017).

14 É digno de nota que uma pesquisa do IBOPE demonstra que, mesmo após o julgamento do STF, 55\% dos brasileiros continuavam contrários ao casamento gay. É claro que o tema da pesquisa é diferente (trata do casamento, e não da união estável), mas certamente permite questionar se a pesquisa "Decisões do Supremo Tribunal Federal", da FGV, não teria um resultado diferente nesse particular se submetida a um universo maior de entrevistados (PESQUISA [...], 2011).

15 Importante dizer que, em aprofundamento da pesquisa "Decisões do Supremo Tribunal Federal" (2011), Fabiana Luci de Oliveira publicaria, em coautoria com Joaquim Falcão, o artigo "O STF e a Agenda Pública Nacional: de outro desconhecido a supremo protagonista?" (2012), no qual os autores sustentam que, mesmo com a discordância dos entrevistados em relação à maioria das decisões do STF (que haviam chegado a seu conhecimento), ainda assim subsistiria o reconhecimento da legitimidade da Corte para tomar essas decisões. 
(em que a lógica de decisões majoritárias/contramajoritárias faz sentido porque os julgamentos se debruçam sobre "temas" jurídicos), mas também como foro especializado para o julgamento penal de altas autoridades da República que tenham prerrogativa de foro (aqui não há "temas" sob análise, mas se opera em juízo binário culpado/inocente).

Como essa competência do STF é largamente exercida em razão dos elevados índices da criminalidade de colarinho branco entre a classe política nacional, e como seus julgamentos nessa seara também acabam sendo muito reverberados pela televisão, ${ }^{16}$ também a percepção popular - positiva ou negativa - acerca desses julgamentos precisaria ser considerada na formulação do "argumento da lealdade constitucional".

Em síntese: a teorização de um sistema adequado de aquisição de capital institucional não pode ser simplificada como uma equação ideal, em que os cidadãos são apresentados mais às decisões majoritárias (com as quais concordam) do que às decisões contramajoritárias (das quais discordam), motivo pelo qual passariam a ter mais "boa vontade" em relação ao Tribunal Constitucional.

Como visto neste artigo, há outras variáveis de âmbito fático que trazem desvios importantes a esse sistema e que precisariam ser levadas em consideração na elaboração do "argumento da lealdade constitucional", em favor do televisionamento de Cortes Constitucionais.

\section{Considerações finais}

As páginas antecedentes mostraram que o televisionamento de tribunais é um tema célebre na pesquisa jurídica norte-americana, tendo atraído a atenção dos estudiosos brasileiros a partir de 2002, com o início das atividades da TV Justiça.

$\mathrm{Na}$ esteira desse interesse, diversas contribuições teóricas foram realizadas pela pesquisa nacional, destacando-se uma, em particular, em defesa do televisionamento de Cortes Constitucionais: trata-se da obra "Jurisdição Constitucional e Participação Popular: o Supremo Tribunal Federal na era da TV Justiça", de autoria de Felipe de Melo Fonte.

Dentre os diversos argumentos do autor em defesa do televisionamento de tribunais, descreveuse aqui o "argumento de lealdade", segundo o qual o televisionamento colabora tanto para a legitimação da jurisdição constitucional (através da teoria do viés da positividade) quanto para a aquisição do lastro institucional (capital institucional), necessário para proferir decisões contramajoritárias sem maiores traumas, o que garantiria as condições necessárias para a adequada tutela dos direitos fundamentais.

Em conclusão, sustenta-se que o "argumento de lealdade constitucional" apresenta lacunas, especialmente quando aplicado ao contexto brasileiro, pois não explica como o sistema de aquisição de capital institucional reage aos desvios decorrentes da seletividade da mídia na formação da pauta dos telejornais (com maior exposição dos julgamentos contramajoritários em detrimento dos majoritários), e também como reage aos desvios decorrentes da percepção popular em relação à atuação do STF no julgamento penal das altas autoridades da República (prerrogativa de foro).

Além disso, se porventura o televisionamento do STF não colaborar efetivamente para o acúmulo de capital institucional, então o "argumento da lealdade constitucional" não sustentará o ponto central de que a prática reforça a independência judicial e fornece melhores condições para a tutela jurisdicional de casos contramajoritários, em especial daqueles que decidem questões relacionadas a direitos fundamentais.

\section{Referências}

AGUIAR, Filipa Moreira Pinheiro. Como decidir o que é notícia? 2016. Relatório de estágio (Mestrado em Comunicação e Jornalismo) - Faculdade de Letras, Universidade de Coimbra, Coimbra, 2016.

16 Sobre o noticiário televisivo da criminalidade política: "[...] a demanda por informações na esfera política é atendida prioritariamente pela mídia, televisiva em particular. Os telejornais seriam uma das principais formas dos cidadãos saberem sobre a corrupção cometida por, ou envolvendo agentes públicos" (COUTINHO; OLIVEIRA FILHO, 2015, p. 150). 
ARENDT, Hannah. Eichmann em Jerusalém: um relato sobre a banalidade do mal. São Paulo: Companhia das Letras, 1999.

BORGES, Fernanda da Silva; ROMANELLI, Sandro Ballande. Supremo espetáculo: Aproximações sobre as imagens públicas do STF. Revista Mediações, Londrina, v. 21, n. 1, p. 199-235, jul./dez. 2016.

BRASIL. Câmara dos Deputados. Projeto de Lei Ordinária n. 7.004, de 18 de dezembro de 2013.

Brasília, DF, 2013. Disponível em: https://www.camara.leg.br/proposicoesWeb/fichadetramitacao?idProp osicao $=604881$. Acesso em: 10 nov. 2018.

CAMPOS, Larissa de Lima. A influência da TV Justiça no processo decisório do STF. Revista de Estudos Empíricos em Direito, São Paulo, v. 4, n. 3, p. 38-56, out. 2017.

CARVALHO, Luiz Maklouf. Data Venia, o Supremo. Como funciona e o que acontece no STF. Revista Piauí, São Paulo, ed. 47, ago. 2010.

COUTINHO, Iluska; OLIVEIRA FILHO, José Tarciso. A cobertura televisiva da corrupção em anos eleitorais: uma análise do enquadramento do caso Petrolão nos noticiários de emissoras pública e comercial. Media \& Jornalismo: uma revista do Centro de Investigação Media e Jornalismo, Coimbra, v. 14, n. 26, p. 149-166, 2015.

DAHL, Robert A. Decision-making in a democracy: the Supreme Court as a National Policy-Maker. Journal of Public Law, [S.I.], v. 6, n. 2, 1957.

EASTON, David. Uma teoria de análise política. Trad. Gilberto Velho. Rio de Janeiro: Zahar, 1968.

ESTADOS UNIDOS DA AMÉRICA. Supreme Court. Public Information Office. Washington, DC, 2017. Disponível em: https://www.supremecourt.gov/publicinfo/PIOServices.pdf. Acesso em: 27 out. 2017.

ESTADOS UNIDOS DA AMÉRICA. U.S. Congress. Senate. Resolution n. 399. Washington, DC, 2009. Disponível em: https://www.congress.gov/bill/111th-congress/senate-resolution/339/text. Acesso em: 01 nov. 2018.

FALCAO, Joaquim; OLIVEIRA, Fabiana Luci de. O STF e a agenda pública nacional: de outro desconhecido a supremo protagonista? Lua Nova, São Paulo, n. 88, p. 429-469, 2013.

FONTE, Felipe de Melo. Jurisdição constitucional e participação popular: o Supremo Tribunal Federal da era da TV Justiça. Rio de Janeiro: Lumens Juris Direito, 2016.

FUNDAÇÃO GETÚLIO VARGAS. Decisões do Supremo Tribunal Federal. Rio de Janeiro: FGV, 2011. Disponível em: https://direitorio.fgv.br/sites/direitorio.fgv.br/files/Pesquisa_STF_Opiniao_Publica.pdf. Acesso em: 01 nov. 2018.

GIBSON, Jamel L.; CALDEIRA, Gregoy A. Citizens, courts, and confirmations: positivity theory and judgements of american people. Princeton: Princeton University Press, 2009.

HARTMANN, Ivar; ALMEIDA, Guilherme da Franca Couto Fernandes de; VALIM, Beatriz Nunes; LIMA, Clarissa Emanuel Leão; MARIANO, Gabriel Borges; NUNES, José Luiz; CAMPOS, Larissa de Lima. A influência da TV Justiça no processo decisório do STF. Revista de Estudos Empíricos em Direito, São Paulo, v. 4, n. 3, p. 38-56, out. 2017.

MARINONI, Luiz Guilherme. Técnica processual e tutela dos direitos. 5. ed. São Paulo: Revista dos Tribunais, 2018.

NOBLAT, Ricardo. A arte de fazer um jornal diário. 7. ed. São Paulo: Contexto, 2008.

OLIVEIRA, Fabiana Luci de. Judiciário e política no Brasil contemporâneo: Um Retrato do Supremo

Tribunal Federal a partir da Cobertura do Jornal Folha de S. Paulo. Revista de Ciências Sociais, Rio de Janeiro, v. 60, n. 4, p. 937-975, 2017.

PESQUISA revela que 55\% dos brasileiros são contra união gay. Último segundo. [S.I.], 28 jul. 2011. Disponível em: https://ultimosegundo.ig.com.br/brasil/pesquisa-revela-que-55-dos-brasileiros-sao-contrauniao-gay/n1597104761368.html. Acesso em: 03 nov. 2018. 
RIBEIRO, Pedro José de Almeida. O conceito de capital institucional e suas características. In: SARMENTO, Daniel (org.). Jurisdição constitucional e política. Rio de Janeiro: Forense: 2015. p. 311350.

SANTOS, Carlos Victor Nascimento dos. O exercício da colegialidade no Supremo Tribunal Federal: entre a construção social do discurso e as práticas judiciárias. 2017. Tese (Doutorado em Direito) Pontifícia Universidade Católica do Rio de Janeiro, Rio de Janeiro, 2017.

SILVA, Virgílio Afonso da; MENDES, Conrado Hübner. Entre a transparência e o populismo judicial. Folha de São Paulo, São Paulo, 11 maio 2009. Disponível em: https://www1.folha.uol.com.br/fsp/ opiniao/fz1105200908.htm. Acesso em: 01 nov. 2018

SILVA, Virgílio Afonso da. Deciding without deliberating. International Journal of Constitutional Law, local, v. 11, 2013.

VIEIRA, Oscar Vilhena. Supremocracia. Revista Direito FGV, São Paulo, v. 4, n. 2, p. 441-464, jul./dez. 2008.

YESAWICH JR., Paul J. Televising and broadcasting trials. Cornell Law Review, [S.I.], v. 37, n. 4, p. 701-717, 1952.

Recebido em: 17/04/2019

Aprovado em: 09/05/2019 